\title{
Optimization of Crude Inulin Extraction from Garlic (Allium sativum L.) Agro-industrial Waste using the Response Surface Methodology.
}

\section{Marco V. Lara-Fiallos}

Universidad Técnica del Norte, Avenida 17 de Julio, Agroindustria/FICAYA, 100105, Ibarra, Imbabura, Ecuador

\section{Leiker A. Bastidas-Delgado}

Universidad Técnica del Norte, Avenida 17 de Julio, Agroindustria/FICAYA, 100105, Ibarra, Imbabura,

Ecuador

\section{Dayana T. Montalvo-Villacreses}

Universidad Técnica del Norte, Avenida 17 de Julio, Agroindustria/FICAYA, 100105, Ibarra, Imbabura,

Ecuador

\section{Rosario C. Espín-Valladares}

Universidad Técnica del Norte, Avenida 17 de Julio, Agroindustria/FICAYA, 100105, Ibarra, Imbabura,

Ecuador

Jimmy Núñez-Pérez

Universidad Técnica del Norte, Avenida 17 de Julio, Agroindustria/FICAYA, 100105, Ibarra, Imbabura, Ecuador

\section{Amaury Pérez Martínez}

Universidad Estatal Amazónica, km 2 Vía Puyo-Tena, Agroindustria/FCT Puyo,160150 Pastaza, Ecuador

\section{Nelson Santiago Vispo}

School of Biological Sciences and Engineering, Yachay Tech University, Hacienda San José s/n y

Proyecto Yachay, Urcuqui 100119, Ecuador

\section{Hortensia Rodríguez Cabrera}

School of Chemical Sciences and Engineering, Yachay Tech University, Hacienda San José s/n y Proyecto Yachay, Urcuqui 100119, Ecuador

\section{Erenio González Suárez}

Universidad Central "Marta Abreu" de Las Villas, Facultad de Química y Farmacia. Departamento de Ingeniería Química, Carretera a Camajuaní, km 5 1⁄2, Santa Clara, Villa Clara, Cuba José Manuel Pais-Chanfrau ( $\sim$ jmpais@utn.edu.ec)

UTN: Universidad Tecnica del Norte https://orcid.org/0000-0003-2829-543X

\section{Research}


Keywords: inulin, Allium sativum L., aqueous extraction, waste valorisation, central composite experimental design, response surface methodology

Posted Date: January 5th, 2021

DOI: https://doi.org/10.21203/rs.3.rs-136719/v1

License: (c) (i) This work is licensed under a Creative Commons Attribution 4.0 International License. Read Full License 


\section{Optimization of crude inulin extraction from garlic (Allium sativum L.)}

\section{2 agro-industrial waste using the response surface methodology.}

3 Marco V. Lara-Fiallos ${ }^{1}$, Leiker A. Bastidas-Delgado ${ }^{1}$, Dayana T. Montalvo-

4 Villacreses ${ }^{1}$, Rosario C. Espín-Valladares ${ }^{1}$, Jimmy Núñez-Pérez ${ }^{1}$, Amaury Pérez

5 Martínez ${ }^{2}$, Nelson Santiago Vispo ${ }^{3}$, Hortensia Rodríguez Cabrera ${ }^{4}$, Erenio González

6 Suárez $^{5}$, José M. Pais-Chanfrau ${ }^{1 *}$

$7 \quad{ }^{1}$ Universidad Técnica del Norte, Avenida 17 de Julio, Agroindustria/FICAYA, 100105,

8 Ibarra, Imbabura, Ecuador.

$9 \quad{ }^{2}$ Universidad Estatal Amazónica, km 2 Vía Puyo-Tena, Agroindustria/FCT

10 Puyo,160150 Pastaza, Ecuador.

$11{ }^{3}$ School of Biological Sciences and Engineering, Yachay Tech University, Hacienda

12 San José s/n y Proyecto Yachay, Urcuqui 100119, Ecuador.

${ }^{4}$ School of Chemical Sciences and Engineering, Yachay Tech University, Hacienda San

14 José s/n y Proyecto Yachay, Urcuqui 100119, Ecuador.

${ }^{5}$ Universidad Central "Marta Abreu” de Las Villas, Facultad de Química y Farmacia.

Departamento de Ingeniería Química, Carretera a Camajuaní, km 5 1⁄2, Santa Clara,

17 Villa Clara, Cuba.

18 Abstract

19 Inulin is a polysaccharide with several applications within the chemical, pharmaceutical,

20 and food industry. It is considered a dietary fibre that provides multiple health benefits.

21 In this work, the yield of raw inulin obtained from garlic agro-industrial useless waste

\footnotetext{
*Correspondence: jmpais@utn.edu.ec
} 
was maximized, by applying the response surface methodology in a central composite design (CCD), in which different distilled-water (DW)-to-garlic-agro-industrial-waste (GAIW) ratios $(3$ and $5 \mathrm{~mL} / \mathrm{g})$ and different temperatures $\left(60\right.$ and $\left.80^{\circ} \mathrm{C}\right)$ were evaluated. Optimal condition was obtained with a DW/GAIW ratio of $4.3 \mathrm{~mL} / \mathrm{g}$ and a temperature of $80.2^{\circ} \mathrm{C}$. Under this condition, the quadratic model showed a maximum yield of crude inulin of $8.17 \pm 0.89 \mathrm{~g} / 100 \mathrm{~g}$. Further, the CCD model obtained was validated with three additional experiments at the same optimal condition. The FTIR spectra of inulin obtained from garlic agro-industrial residues and chicory inulin showed similarities and differences, presumably related to the different degrees of polymerization of the fructans present.

Keywords: inulin, Allium sativum L., aqueous extraction, waste valorisation, central composite experimental design, response surface methodology.

\section{Introduction}

Garlic (Allium sativum L.) is an aromatic crop native to Central Asia, although its cultivation has spread throughout the five continents, and has been widely used as a condiment for the preparation of numerous dishes in different countries (Charron et al. 2016). Additionally, the positive effects of garlic consumption on health are well known and documented (Suleria et al. 2015; Ried 2016; Shang et al. 2019).

China is the world's leading producer ( $>20$ million tons per year, about $80 \%$ of the worldwide production) and consumer of garlic. Among the first ten garlic producing countries are India, Bangladesh, Egypt, South Korea, Russia, and Ukraine, all with production levels above 100,000 tons per year (FAO 2019).

By 2012, more than 3.7 million tons of garlic by-products were generated from the garlic processing industry (Kallel and Chaabouni 2017), representing more than 15\% of 
the whole worldwide production (FAO 2019). The damages cloves, straw and husk can be utilized to extract bioactive compounds (Dietrich et al. 2016; El-Mashad et al. 2019) like dietary fiber (Chandrashekara and Venkatesh 2016), polysaccharides (Hughes et al. 2017), polyphenols (Ichikawa et al. 2003), cellulose (Reddy and Rhim 2018), lignin, and to absorb the heavy metals (Liu et al. 2014; Chen et al. 2018). Instead, it is dismissed and burned as a waste product contributing to global warming without any kind of benefits.

There are inadequacies in waste management due to aspects such as insufficient economic resources, technological capacity, and regulations that regulate and guarantee integral management of said waste from its generation to its final disposal (Bernache Pérez 2015).

\section{Plant-based agro-industrial wastes are especially attractive sources for waste} valorisation because of their content in chemical compounds (like sugars, pigments, food fiber, protein, polyphenols, lignin, etc.) and can be potentially useful when chemical or microbiological treatments transform them into products of high added value (Moldes et al. 2002; Otles and Kartal 2018; Galanakis 2021).

Through the valorisation of agro-industrial waste, the portfolio of valuable products of agro-industrial companies could be increased, improving their competitiveness, and obtaining increasingly efficient and sustainable agro-industrial processes (Hiloidhari et al. 2020; Galanakis 2021).

Inulin is a non-digestible fructan-type polysaccharide found in many plants as a storage carbohydrate, usually in vegetables, fruits, and cereals of important nutritional properties (Franck 2002, 2016; Apolinário et al. 2014; Shalini et al. 2017). Inulin can be used as an industrial food ingredient improving organoleptic characteristics, the stability 
of foams and emulsions, and as a fat substitute offering an advantage in taste and texture (Panesar and Bali 2016; Shoaib et al. 2016; James et al. 2017; Singh et al. 2017). Inulin acts as a dietary fibre providing health benefits, contributes to the decrease of lipid levels, blood glucose and pressure, and laxative action, due to its prebiotic effect (Choque Delgado and Tamashiro 2018; Ghaffari and Roshanravan 2020; Guarino et al. 2020), prevents the development of colon cancer (Pool-Zobel and Sauer 2007). It has also been reported that the use of inulin produces an increase in the absorption of cations and magnesium, an increase in the excretion of sulfur, and a decrease in uremia (Wang and Gibson 1993; Jung et al. 2015).

$$
\text { Inulin is soluble in water (Yanovsky and Kingsbury 1933), and fractions with a }
$$
higher degree of polymerization can be precipitated with ethanol (Ku et al. 2003). For this reason, the extraction with hot water and its partial purification utilizing ethanol precipitation has been used as a common method of obtaining commercial inulin from different natural sources (Niness 1999; Álvarez-Borroto et al. 2015). In the masstransfer process of solid-liquid extraction of inulin from its natural plant sources to hot water, however, in addition to the hot water/solid ratio and the water temperature, other factors such as the extraction time, $\mathrm{pH}$, and the agitation of the mixture could exert certain influence (Lingyun et al. 2007; Rubel et al. 2018).

The goal of the present work is to determine the optimal conditions that maximize the inulin yield in garlic industrial wastes, through the selection of the best choice of the hot water/weight of garlic waste ratio and temperature, using a central composite design of experiments in the response surface methodology.

\section{Materials and methods}

\section{Raw material and its preparation}


Garlic agro-industrial waste was supplied by "Industrial Productos Moro scc" (Ibarra, Imbabura, Ecuador). Garlic agro-industrial wastes (GAIWs) are formed by damaged bulbs, husks and the garlic paste lumps formed after cooking.

GAIWs were washed and disinfected with a $1 \%(\mathrm{v} / \mathrm{v})$ ethanol solution before use, then was washed with abundant distilled water, and dried overnight at $80{ }^{\circ} \mathrm{C}$ in an oven. Dried GAIWs were chopped with the help of a crusher and a $4 \mathrm{~mm}$ of sieve mesh, to obtain a size of the homogeneous particle.

\section{Experimental conditions}

GAIWs were subjected to a solid-liquid extraction process, by using distilled water (DW) as a solvent with two different water-to-weight-of-GAIW ratios (3 and $5 \mathrm{~mL}$ of DW per gram of GAIW), combined with two temperature levels (70 and $\left.90{ }^{\circ} \mathrm{C}\right)$.

Thirty grams (30 g) GAIWs was used for all treatments, and the extraction time was 45 min with constant agitation of $200 \mathrm{rpm}$ (Franck 2016). Subsequently, the first filtration was performed using $0.5 \mu \mathrm{m}$ filter paper, and the clear obtained was adjusted to $\mathrm{pH} 10.2$ with $0.1 \mathrm{M} \mathrm{CaCO}_{3}$ at a temperature of $60{ }^{\circ} \mathrm{C}$ with constant stirring of 200 rpm, for $30 \mathrm{~min}$. Then to remove different components of the waste, such as fats and proteins, the extract was adjusted to $\mathrm{pH} 8$ with $0.1 \mathrm{~N} \mathrm{HCl}$ and filtered again, to remove the sediments and impurities generated during the carbonation process inulin and in this way, the crude extract of inulin was obtained (Chacón-Villalobos 2006; EscobarLedesma 2017; Pinango Cuacango 2019).

\section{Inulin Determination}

To determine the inulin content in the purified extracts, a UV-visible spectrometry. Inulin from chicory (I2255, Sigma-Aldrich) was used to elaborate a reference curve based on the Beer-Lambert's law in which the absorbance at a wavelength of $715 \mathrm{~nm}$ 
was correlated against the knowing concentration of inulin following the procedure described elsewhere (Park and Johnson 1949; Hizukuri et al. 1981).

\section{Infrared Spectroscopy (IR) Characterization}

The IR analysis of the reference material and purified samples were performed at room temperature on an IR Agilent Cary 630 FTIR model in a wavenumber range from 600 to $4000 \mathrm{~cm}^{-1}$ at 32 scans with a resolution of $4 \mathrm{~cm}^{-1}$. An ATR sampling technique was used on a single bounce diamond crystal.

FTIR is a suitable technique to study the physicochemical properties of inulin, which constitutes a mixture of polysaccharides of different degrees of polymerization

(Romano et al. 2018).

\section{Statistical optimization of the extraction conditions of crude inulin from garlic} agro-industrial wastes

The central composite experimental design (CCD) of the response surface methodology (RSM) was executed (Myers et al. 2016; Yolmeh and Jafari 2017), to find the combination of the DW-to-mass of GAIW ratio and the temperature that maximizes the raw inulin yield. All experiments were planned and analyzed using the ExpertDesign 11.0.3.0 statistical package (Stat-Ease, Inc., Minneapolis, USA).

The response variable (crude (non-purified) inulin yield) was adjusted to a secondorder statistical model described by the following equation:

$$
Y=\beta_{0}+\sum_{i=1}^{2} \beta_{i 1} X_{i}+\sum_{i=1}^{2} \beta_{i 2} X_{i}^{2}+\sum_{i=1}^{1} \beta_{i+2, i+2} X_{i} X_{i+1}+\varepsilon
$$

Where $Y$ is the yield of crude inulin (g of crude inulin/100 $\mathrm{g}$ of GAIW or \% (w/w)); $\beta_{0}$ is the average value of all effects in the model; $\beta_{11}$ represents the effect of factor $X_{1}$ $(R, \mathrm{~mL} / \mathrm{g}) ; \beta_{21}$ represents the effect of factor $X_{2}\left(T,{ }^{\circ} \mathrm{C}\right) ; \beta_{12}$ represents the quadratic 
141 effect of factor $X_{1} ; \beta_{22}$ represents the quadratic effect of factor $X_{2}$, and $\beta_{33}$ is the effect

142 of the interaction of factors $X_{1}$ and $X_{2}$. The $\varepsilon$ is the random model error caused by other 143 sources of variability not considered in this model.

\section{Results and discussion}

The actual and coded values of the independent variables and the response obtained by both the quadratic model and the experimental values are presented in Table 1 .

\section{TABLE 1}

The quadratic equations in terms of coded and real factors obtained were:

The analysis of variance (ANOVA) of the model is shown in Table 2. An F-value of 168.81 implies that the model is significant. All p-values were significant in the model $(\mathrm{p}<0.05)$, except the one associated with $X_{2}$ that is included in the model to guarantee can be used to fit the experimental data.

\section{TABLE 2}

The suggested model can be used to find the maximum value of yield based on a combination of $R$ and $T$, as shown, among others the $\mathrm{R}^{2}, \mathrm{R}^{2}$-adjusted and signal to noise ratio (adequate precision > 4) values (Table 3), and, by the graphs of the normal-plot of residues (Fig. 1A) and in the relationship between predicted vs. actual $Y$-values (Fig. 1B).

\section{FIGURE 1}

TABLE 3 
3D-Graph of the crude inulin yield $(Y, \mathrm{~g} / 100 \mathrm{~g})$ with the solvent/raw material ratio $(R, \mathrm{~mL} / \mathrm{g})$ and the temperature $\left(T,{ }^{\circ} \mathrm{C}\right)$ shows the existence of an absolute maximum value inside of experimental surface for the yield (Fig. 2A), which was determined by a numerical algorithm by the Design-Expert software (Fig. 2B).

A unique optimal point was obtained, close to the central point, for $R^{*}=4.3 \mathrm{~mL} / \mathrm{g}$ and $T^{*}=80.2{ }^{\circ} \mathrm{C}$, which maximizes the model of crude inulin yield $Y_{\max }=8.169 \pm$ $0.815 \mathrm{~g} / 100 \mathrm{~g}$ of garlic waste (Fig. 2B).

\section{FIGURE 2}

Three similar experiments were performed to validate the suggested model using the optimal point $\left(R^{*}\right.$ and $\left.T^{*}\right)$. The average result obtained, as well as the individual values, are within the range of values predicted by the model, which confirms the accuracy of the quadratic regression model for the crude inulin yield (Table 4).

\section{TABLE 4}

The results presented here are somewhat lower than the values reported in other reports (Wang et al. 2015). The amount of inulin in garlic bulbs is between 9-16 g/100 g (Madrigal and Sangronis 2007; Lara-Fiallos et al. 2017). A value of $9.80 \pm 0.03 \mathrm{~g} / 100 \mathrm{~g}$ for garlic bulbs and statistically similar values for onion (Allium cepa L.), leek (Allium porrum L.) and dandelion (Taraxacum officinale) have been reported elsewhere (Monroy-Rodríguez 2010). These values are between 11.1-50\% above the amounts reported in the present study. The difference is probably because, in the present investigation, the industrial residues of garlic were used, whereas, in the mentioned investigations, the whole bulbs of the commercial and edible parts of garlic are used.

Other factors that could influence the extraction yield of inulin from GAIWs, like the extraction time and the power of stirring the mixture, are not considered in this 
investigation, not to extend the experimentation time (it would go from 13 for two variables to 30 experimental runs for four) and because the stirring power and the extraction time would be easily adjustable parameters of the process if it were decided to establish this process on a productive scale.

To validate the inulin-type nature of the purified sample obtained under the optimal extraction condition reached in this study, FTIR analysis of such a purified sample (PS) and the reference material (RM) from Sigma-Aldrich (inulin from chicory, I2255) were carried out (Fig. 3).

\section{FIGURE 3}

By using IR-analysis the main contributions of chemical groups of inulin were determined and summarized (Table 5).

\section{TABLE 5}

Among others, the peaks observed at $3280 \mathrm{~cm}^{-1}(\mathrm{RM})$ and $3254 \mathrm{~cm}^{-1}$ (PS) were assigned to the stretch $(\mathrm{O}-\mathrm{H})$ of $(\mathrm{R})_{2}-\mathrm{CH}-\mathrm{OH}$ and $\mathrm{R}-\mathrm{CH}_{2}-\mathrm{OH}$ groups of alcohol chains. The peaks at $2883 \mathrm{~cm}^{-1}$ (in both RM and PS) assigned to C-H stretching vibrations indicated the presence of alkanes type of $(\mathrm{R})_{3}-\mathrm{CH}$, while the peaks at $2930 \mathrm{~cm}^{-1}(\mathrm{RM})$ and $2932 \mathrm{~cm}^{-1}$ (PS) corresponds with strong asymmetrical stretching vibrations of the group $\mathrm{C}-\mathrm{H}$ of alkanes type $\mathrm{R}-\mathrm{CH}_{2}-\mathrm{R}$.

The most variable region of the FTIR spectrum among inulin's of different origin is $1500-800 \mathrm{~cm}^{-1}$ (Fig. 3), which is presumably due to the difference between the degrees of polymerization of the mixture of polysaccharides that form the inulin between the reference material (obtained from chicory) and the studied sample (obtained from garlic waste). A similar area of the FTIR spectrum $\left(1450-900 \mathrm{~cm}^{-1}\right)$ was reported in another study where the greatest differences observed between two inulin samples were found, 
formed by mixtures of oligosaccharides and polysaccharides, one of low and the other

213 of the high degree of polymerization (Romano et al. 2018).

\section{Conclusions}

By using a CCD in the RSM, a quadratic model of the yield of crude (non-purified) inulin extraction from industrial garlic wastes with two independent variables were obtained. This research showed an optimal yield of around $8 \mathrm{~g}$ of crude inulin per $100 \mathrm{~g}$ of GAIW. Although this value is lower than inulin obtained from a whole bulb of commercial garlic, even so, maybe attractive enough to implement an industrial process to produce inulin from agro-industrial garlic useless waste. To add this product to company's portfolio further studies must demonstrated the economic feasibility

222 production of crude inulin from GAIW.

\section{Acknowledgements}

224 We would like to thank the authorities of the Faculty and especially to Dean Dr.

Bolívar Batallas for providing us with the facilities and equipment for carrying out this investigation. This research was executed within the collaboration agreement between

227 the company "Industrial Productos Moro" and the North's Technical University.

\section{Abbreviations}

229 ANOVA: Analysis of variance; CCD: central composite design; DW: distilled water; FTIR: Fourier-transformed infra-red spectra; GAIWs: garlic agro-industrial wastes; IR: infra-red spectra; PS: purified sample; RM: reference material; RSM: response surface

232 methodology.

\section{Authors' contributions}

MVLF and EGS conceived and designed the experiments. LABD, DTMV, RCEV, and JNP performed experiments. APM, NSV, and HRC provided important technical 
support for experiments. JMPC elaborated and reviewed the manuscript. All authors

237 discussed the results, and all authors read and approved the final manuscript.

\section{Funding}

239 Not applicable.

240 Availability of data and materials

241 All data obtained or analyzed during this study are included in this article and available

242 from the corresponding author.

243 Ethics approval and consent to participate.

244 Not applicable.

\section{Consent for publication}

246 The publication of the paper has been agreed by the authors.

247 Competing Interests

248 The authors declare that they have no competing interests.

\section{References}

250 Álvarez-Borroto R, Ruano-Nieto AL, Calle-Miñaca MR, Lara-Fiallos MV (2015)

251 Extracción y determinación de inulina del ajo común autóctono (Allium sativum).

252 Rev Cuba Quím 27:131-146

253

254

255

256

257

Apolinário AC, De Lima Damasceno BPG, De Macêdo Beltrão NE, et al (2014) Inulintype fructans: A review on different aspects of biochemical and pharmaceutical technology. Carbohydr Polym 101:368-378. doi: 10.1016/j.carbpol.2013.09.081

Bernache Pérez G (2015) La gestión de los residuos sólidos : un reto para los gobiernos locales. Soc y Ambient 1:72-98

Chacón-Villalobos A (2006) Perspectivas Agroindustriales Actuales de los 
Chandrashekara PM, Venkatesh YP (2016) Immunostimulatory properties of fructans derived from raw garlic (Allium sativum L.). Bioact Carbohydrates Diet Fibre 8:65-70. doi: 10.1016/j.bcdf.2016.11.003

Charron CS, Milner JA, Novotny JA (2016) Garlic. In: Caballero B, Finglas P, Toldrá F (eds) Encyclopedia of Food and Health (Vol. 3). Elsevier Ltd., London, UK, pp

Dietrich T, Villaran Velasco M del C, Echeverría PJ, et al (2016) Crop and Plant

Choque Delgado GT, Tamashiro WM da SC (2018) Role of prebiotics in regulation of microbiota and prevention of obesity. Food Res Int 113:183-188. doi: 10.1016/j.foodres.2018.07.013

Biomass as Valuable Material for BBB. Alternatives for Valorization of Green Wastes. In: Poltronieri P, D’Urso OF (eds) Biotransformation of Agricultural Waste and By-Products: The Food, Feed, Fibre, Fuel (4F) Economy. Elsevier Inc, Amsterdam, pp 1-19

El-Mashad HM, Zhang RH, Pan Z (2019) Onion and Garlic. In: Pan Z, Zhang RH, Zicari S (eds) Integrated Processing Technologies for Food and Agricultural ByProducts, 1st edn. Elsevier Inc., London, pp 273-295 

variedades de plantas de cultivos no tradicionales del Ecuador. Escuela Politécnica Nacional (EPN)

FAO (2019) FAOSTAT, Crops. In: Food Agric. Organ. United Nations, Database Crop.

Franck A (2002) Technological functionality of inulin and oligofructose. Br J Nutr 87:S287-S291. doi: 10.1079/bjn/2002550

Franck A (2016) Inulin. In: Stephen AM, Phillips GO, Williams PA (eds) Food Polysaccharides and Their Applications, 2nd edn. CRC Press, Boca Raton, pp 335351

Galanakis CM (2021) Food waste valorization opportunities for different food industries. In: Galanakis CM (ed) The Interaction of Food Industry and Environment, 1st edn. Elsevier Inc, London, UK, pp 341-422

Ghaffari S, Roshanravan N (2020) The role of nutraceuticals in prevention and treatment of hypertension: An updated review of the literature. Food Res Int 128:. doi: 10.1016/j.foodres.2019.108749

Guarino MPL, Altomare A, Emerenziani S, et al (2020) Mechanisms of action of prebiotics and their effects on gastro-intestinal disorders in adults. Nutrients 12:124. doi: $10.3390 /$ nu12041037

Hiloidhari M, Bhuyan N, Gogoi N, et al (2020) Agroindustry wastes: Biofuels and biomaterials feedstocks for sustainable rural development. In: R. Praveen Kumar, Edgard Gnansounou, Jegannathan Kenthorai Raman, Gurunathan Baskar (eds) Refining Biomass Residues for Sustainable Energy and Bioproducts: Technology, Advances, Life Cycle Assessment, and Economics, 1st edn. Academic Press, 
304

Hizukuri S, Takeda Y, Yasuda M, Suzuki A (1981) Multi-branched nature of amylose and the action of debranching enzymes. Carbohydr Res 94:205-213. doi: $10.1016 / \mathrm{S} 0008-6215(00) 80718-1$

Hughes SR, Qureshi N, López-Núñez JC, et al (2017) Utilization of inulin-containing waste in industrial fermentations to produce biofuels and bio-based chemicals. World J Microbiol Biotechnol 33:1-15. doi: 10.1007/s11274-017-2241-6

Ichikawa M, Ryu K, Yoshida J, et al (2003) Identification of Six Phenylpropanoids from Garlic Skin as Major Antioxidants. J Agric Food Chem 51:7313-7317. doi: 10.1021/jf034791a

James M, Velastegui E, Cruz M. (2017) Evaluación de las condiciones de cultivo de Lactobacillus acidophilus y Lactobacillus casei a nivel de laboratorio, con inulina como fuente de carbono. Bionatura 2:235-240. doi: 10.21931/rb/2017.02.01.4

Jung TH, Jeon WM, Han KS (2015) In vitro effects of dietary inulin on human fecal microbiota and butyrate production. J Microbiol Biotechnol 25:1555-1558. doi: 10.4014/jmb.1505.05078

Kallel F, Chaabouni SE (2017) Perspective of garlic processing wastes as low-cost substrates for production of high-added value products: A review. Environ Prog Sustain Energy 36:1765-1777. doi: 10.1002/ep.12649

Ku Y, Jansen O, Oles CJ, et al (2003) Precipitation of inulins and oligoglucoses by ethanol and other solvents. Food Chem 81:125-132. doi: 10.1016/S03088146(02)00393-X 
Lara-Fiallos M V., Julian Ricardo M, Calle Miñaca M, et al (2017) Technological proposal for a garlic-derived inulin extraction process. In: MOL2NET 2017, International Conference on Multidisciplinary Sciences, 3rd edition session MODEC-02: Workshop on Natural Products and Agro-Industrial Procesess in Amazon, UEA, Puyo, Ecuador, 2017. MDPI, Puyo, Ecuador, pp 1-4

Lingyun W, Jianhua W, Xiaodong Z, et al (2007) Studies on the extracting technical conditions of inulin from Jerusalem artichoke tubers. J Food Eng 79:1087-1093. doi: 10.1016/j.jfoodeng.2006.03.028

Liu W, Liu Y, Tao Y, et al (2014) Comparative study of adsorption of Pb(II) on native garlic peel and mercerized garlic peel. Environ Sci Pollut Res 21:2054-2063. doi: $10.1007 / \mathrm{s} 11356-013-2112-0$

Madrigal L, Sangronis E (2007) La inulina y derivados como ingredientes claves en alimentos funcionales. Arch Latinoam Nutr 57:387-396

Moldes AB, Cruz JM, Domínguez JM (2002) Production of a cellulosic substrate susceptible to enzymatic hydrolysis from prehydrolyzed barley husks. Agric Food Sci Finl 11:51-58. doi: 10.23986/afsci.5712

Monroy-Rodríguez W (2010) Determinación de inulina en once especies vegetales. Universidad Autónoma Agraria “Anonio Narro”, Buena Vista, Saltillo, Coahuila, México

Myers R, Montgomery D, Anderson-Cook C (2016) Response Surface Methodology: Process and Product Optimization Using Designed Experiments, 4th ed. John Wiley \& Sons, Inc, Hoboken, New Jersey 
347 Niness KR (1999) Inulin and oligofructose: What are they? J Nutr 129:1402S-1406S. doi: 10.1093/jn/129.7.1402s

Otles S, Kartal C (2018) Food Waste Valorization. In: Galanakis CM (ed) Sustainable Food Systems from Agriculture to Industry, 1st edn. Academic Press, London, UK, pp 371-399

Panesar PS, Bali V (2016) Prebiotics. In: Encyclopedia of Food and Health. pp 464-471

Park JT, Johnson MJ (1949) A submicron determination of glucose. J Biol Chem $181: 149-151$

Pinango Cuacango RO (2019) Extracción de inulina de dos variedades de tuna (Opuntia ficusindica) color roja y blanca del Valle del chota por lixiviación. Universidad Técnica del Norte

Pool-Zobel BL, Sauer J (2007) Overview of Experimental Data on Reduction of Colorectal Cancer Risk by Inulin-Type Fructans. J Nutr 137:2580S-2584S. doi: $10.1093 / \mathrm{jn} / 137.11 .2580 \mathrm{~s}$

Reddy JP, Rhim JW (2018) Extraction and Characterization of Cellulose Microfibers from Agricultural Wastes of Onion and Garlic. J Nat Fibers 15:465-473. doi: $10.1080 / 15440478.2014 .945227$

Ried K (2016) Garlic Lowers Blood Pressure in Hypertensive Individuals, Regulates Serum Cholesterol, and Stimulates Immunity: An Updated Meta-analysis and Review. J Nutr 146:389S-396S. doi: 10.3945/jn.114.202192

Romano N, Araujo-Andrade C, Lecot J, et al (2018) Infrared spectroscopy as an alternative methodology to evaluate the effect of structural features on the 
physical-chemical properties of inulins. Food Res Int 109:223-231. doi: 10.1016/j.foodres.2018.04.032

Rubel IA, Iraporda C, Novosad R, et al (2018) Inulin rich carbohydrates extraction from Jerusalem artichoke (Helianthus tuberosus L.) tubers and application of different drying methods. Food Res Int 103:226-233. doi: 10.1016/j.foodres.2017.10.041

Shalini R, Abinaya G, Saranya P, Antony U (2017) Growth of selected probiotic bacterial strains with fructans from Nendran banana and garlic. LWT - Food Sci Technol 83:68-78. doi: 10.1016/j.lwt.2017.03.059

Shang A, Cao SY, Xu XY, et al (2019) Bioactive compounds and biological functions of garlic (allium sativum L.). Foods 8:1-32. doi: 10.3390/foods8070246

Shoaib M, Shehzad A, Omar M, et al (2016) Inulin: Properties, health benefits and food applications. Carbohydr Polym 147:444-454. doi: 10.1016/j.carbpol.2016.04.020

Singh SP, Jadaun JS, Narnoliya LK, Pandey A (2017) Prebiotic Oligosaccharides: Special Focus on Fructooligosaccharides, Its Biosynthesis and Bioactivity. Appl Biochem Biotechnol 183:613-635. doi: 10.1007/s12010-017-2605-2

Suleria HAR, Butt MS, Khalid N, et al (2015) Garlic (Allium sativum): Diet based therapy of 21st century-a review. Asian Pacific J Trop Dis 5:271-278. doi: $10.1016 / \mathrm{S} 2222-1808(14) 60782-9$

Wang X, Gibson GR (1993) Effects of the in vitro fermentation of oligofructose and inulin by bacteria growing in the human large intestine. J Appl Bacteriol 75:373380. doi: 10.1111/j.1365-2672.1993.tb02790.x

Wang Y, Pedersen CM, Qiao Y, et al (2015) In situ NMR spectroscopy: Inulin biomass 

3663. doi: 10.1021/ja01336a029

398

399

A

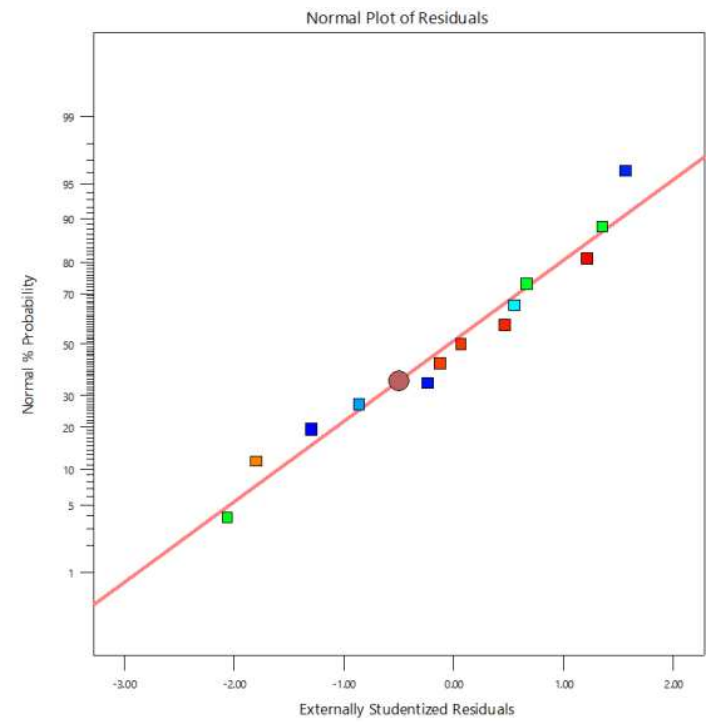

B

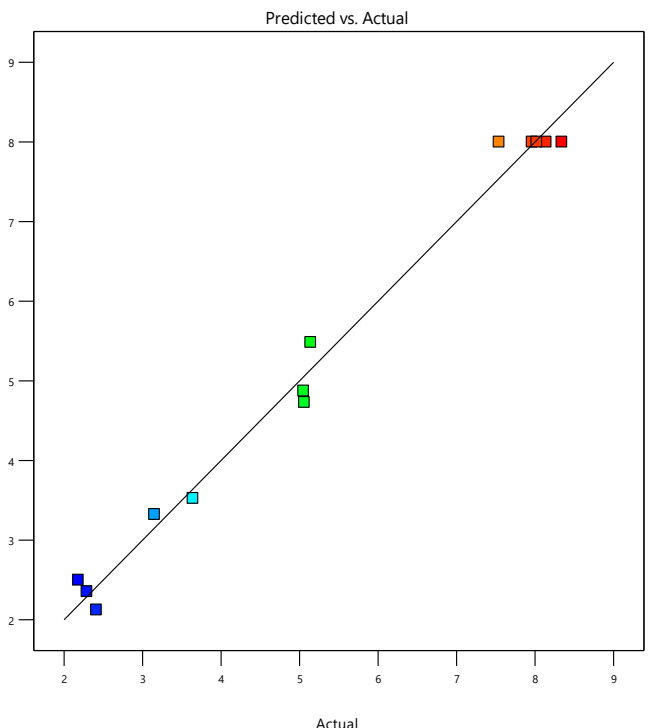

400 Fig. 1 (A) Normal plot of residuals and (B) predicted vs. actual values for the quadratic

401 model of yield with a ration of solvent/mass of garlic waste and temperature of solvent 402 extraction. 

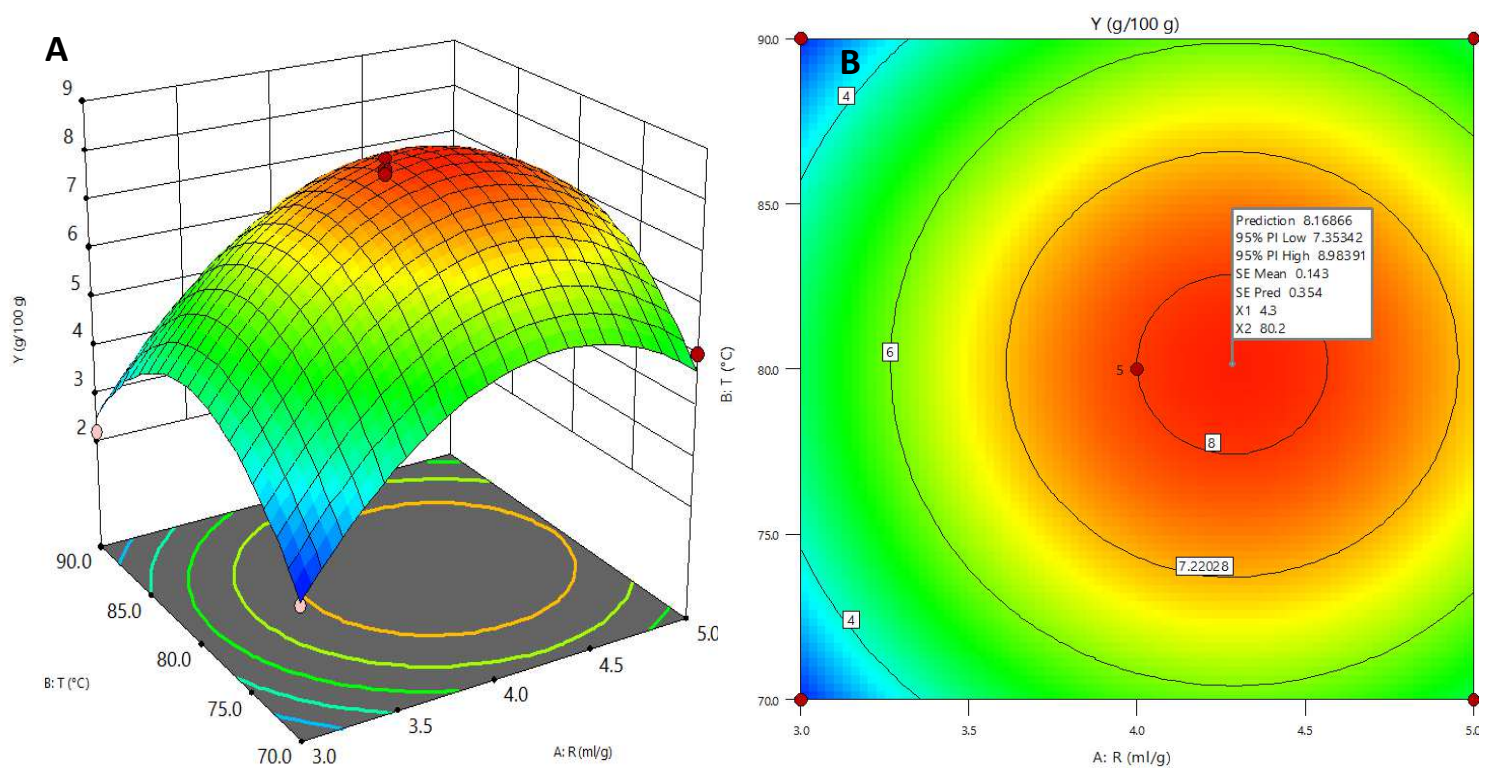

406

Fig. 2 (A) 3D-graph representation of the quadratic model with experimental points, and

407

(B) Contour representation of the model with the optimal value of $Y_{\max }=8.167 \mathrm{~g} / 100 \mathrm{~g}$ of garlic waste at $\mathrm{R}^{*}=4.3 \mathrm{~mL} / \mathrm{g}$ and $\mathrm{T}^{*}=80.2{ }^{\circ} \mathrm{C}$. 


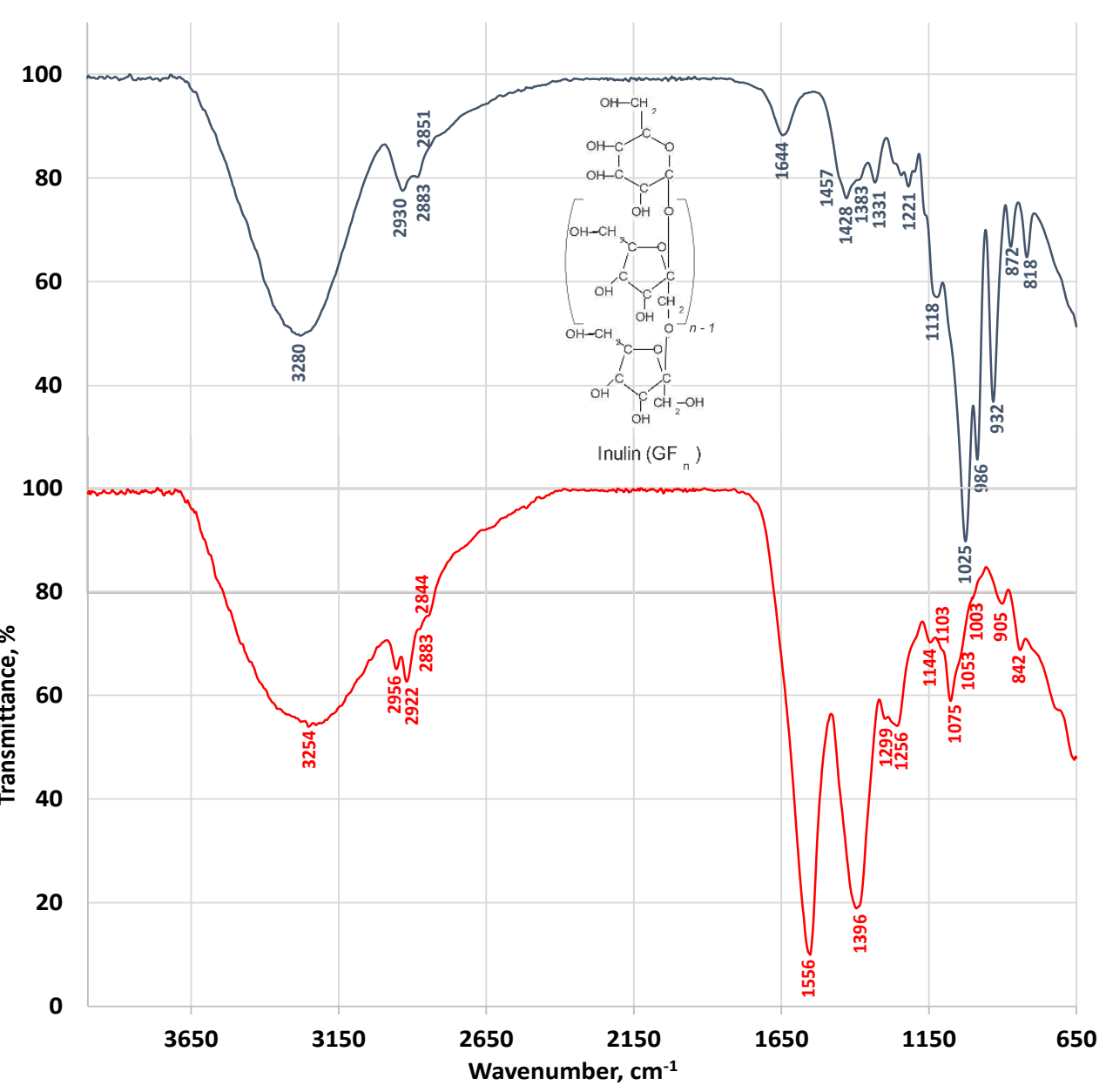

409

410 Fig. 3 FTIR spectrum of reference material from Sigma-Aldrich (RM, upper) and purified 411 sample (PS, lower).

412 


\section{TABLES}

414

415 Table 1 Actual and predicted results for the response variable (Y: inulin yield

$416(\mathrm{~g} / 100 \mathrm{~g}))$ obtained by the quadratic model based on the independent variables $\left(\mathrm{X}_{1}\right.$ :

$417 \mathbf{R}(\mathrm{mL} / \mathrm{g})$ and $\left.\mathrm{X}_{2}: \mathrm{T}\left({ }^{\circ} \mathrm{C}\right)\right)$.

\begin{tabular}{|c|c|c|c|c|c|c|}
\hline \multirow{2}{*}{ Run } & \multicolumn{2}{|l|}{$X_{1}: R$} & \multicolumn{2}{|l|}{$X_{2}: T$} & \multicolumn{2}{|c|}{ Response $(Y, \mathrm{~g} / 100 \mathrm{~g})$} \\
\hline & coded & actual $(R, \mathrm{~mL} / \mathrm{g})$ & coded & $\operatorname{actual}\left(T,{ }^{\circ} \mathrm{C}\right)$ & model & actual \\
\hline 1 & +1.41 & 5.4 & 0.00 & 80.0 & 5.55 & 5.14 \\
\hline 2 & +1.00 & 5.0 & -1.00 & 70.0 & 4.73 & 5.06 \\
\hline 3 & 0.00 & 4.0 & 0.00 & 80.0 & 8.00 & 8.34 \\
\hline 4 & -1.41 & 2.6 & 0.00 & 80.0 & 2.23 & 2.41 \\
\hline 5 & 0.00 & 4.0 & 0.00 & 80.0 & 8.00 & 8.02 \\
\hline 6 & -1.00 & 3.0 & +1.00 & 90.0 & 2.50 & 2.18 \\
\hline 7 & +1.00 & 5.0 & +1.00 & 90.0 & 4.87 & 5.05 \\
\hline 8 & 0.00 & 4.0 & +1.41 & 94.1 & 3.55 & 3.64 \\
\hline 9 & 0.00 & 4.0 & 0.00 & 80.0 & 8.00 & 7.54 \\
\hline 10 & 0.00 & 4.0 & -1.41 & 65.9 & 3.35 & 3.15 \\
\hline 11 & -1.00 & 3.0 & -1.00 & 70.0 & 2.36 & 2.29 \\
\hline 12 & 0.00 & 4.0 & 0.00 & 80.0 & 8.00 & 7.96 \\
\hline 13 & 0.00 & 4.0 & 0.00 & 80.0 & 8.00 & 8.14 \\
\hline
\end{tabular}

418

419 
420 Table 2 ANOVA of the performance of the quadratic model of the yield of crude

421 inulin with the solvent-to-weight of garlic wastes ratio and temperature of solvent

422 extraction.

\begin{tabular}{|c|c|c|c|c|c|c|}
\hline Source & Sum of Squares & $\mathrm{df}$ & Mean Square & F-value & p-value & \\
\hline Model & 70.63 & 4 & 17.66 & 168.81 & $<0.0001$ & significant \\
\hline$X_{1}-R$ & 11.28 & 1 & 11.28 & 107.87 & $<0.0001$ & \\
\hline$X_{2}-T$ & 0.041 & 1 & 0.041 & 0.3923 & 0.5485 & \\
\hline$X_{1}^{2}$ & 30.61 & 1 & 30.61 & 292.59 & $<0.0001$ & \\
\hline$X_{2}^{2}$ & 36.40 & 1 & 36.40 & 348.00 & $<0.0001$ & \\
\hline Residual & 0.8368 & 8 & 0.1046 & & & \\
\hline Lack of Fit & 0.4880 & 4 & 0.1220 & 1.4 & 0.3764 & not significant \\
\hline Pure Error & 0.3488 & 4 & 0.0872 & & & \\
\hline Cor Total & 71.47 & 12 & & & & \\
\hline
\end{tabular}

423

424 
425 Table 3 Fit statistic values of the quadratic model for the yield of crude inulin from

426 garlic wastes with solvent-to-weight of garlic wastes ratio and temperature of

427 solvent extraction.

\begin{tabular}{ll|ll}
\hline Std. Dev. & 0.3234 & $\mathrm{R}^{2}$ & 0.9883 \\
Mean & 5.3015 & Adjusted R & 0.9824 \\
C.V.\% & 6.1005 & Predicted $\mathrm{R}^{2}$ & 0.9594 \\
& & Adequate Precision & 29.2881 \\
\hline
\end{tabular}

428

429 
430

Table 4 Results of validation experiments.

\begin{tabular}{llllllll}
\hline Response & Pred. Mean & Std. Dev. & n & SE Pred. & 95\% PI low & Data Mean & 95\% PI high \\
\hline$Y(\mathrm{~g} / 100 \mathrm{~g})$ & 8.169 & 0.323 & 3 & 0.235 & 7.627 & 8.023 & 8.711
\end{tabular}

431

432 
Table 5 Main peaks of the FTIR spectrum of inulin and the reference material

434 (RM) and purified sample (PS).

\begin{tabular}{|c|c|c|c|c|c|}
\hline \multirow[t]{2}{*}{ Classifications } & \multirow[t]{2}{*}{ Group } & \multirow[t]{2}{*}{ Bond } & \multirow[t]{2}{*}{ Intensity } & \multicolumn{2}{|c|}{ Wavelength peak, $\mathrm{cm}^{-1}$} \\
\hline & & & & Range & Actual \\
\hline \multirow[t]{3}{*}{ Alcohols } & $(\mathrm{R})_{2}-\mathrm{CH}-\mathrm{OH}$ & $\mathrm{O}-\mathrm{H}$ & variable & $3400-3200$ & RM: 3280; PS: 3254 \\
\hline & & $\mathrm{O}-\mathrm{H}$ & strong & $1350-1260$ & RM: 1331; PS: 1299 \\
\hline & & $\mathrm{C}-\mathrm{O}$ & strong & $1125-1090$ & RM: 1118; PS: 1103 \\
\hline \multirow[t]{3}{*}{ Alcohols } & $\mathrm{R}-\mathrm{CH}_{2}-\mathrm{OH}$ & $\mathrm{O}-\mathrm{H}$ & variable & $3400-3200$ & RM: 3280; PS: 3254 \\
\hline & & $\mathrm{O}-\mathrm{H}$ & medium & $1480-1410$ & RM: 1428,1457 ; PS: overlapping \\
\hline & & $\mathrm{C}-\mathrm{O}$ & strong & $1075-1000$ & RM: 1025; PS: 1003,1053,1075 \\
\hline \multirow[t]{2}{*}{ Alkanes } & $(\mathrm{R})_{3}-\mathrm{CH}$ & $\mathrm{C}-\mathrm{H}$ & weak & $2900-2880$ & RM: 2883; PS: 2883 \\
\hline & & $\mathrm{C}-\mathrm{H}$ & weak & $1350-1320$ & RM: 1331; PS: overlapping \\
\hline \multirow[t]{3}{*}{ Alkanes } & $\mathrm{R}-\mathrm{CH}_{2}-\mathrm{R}$ & $\mathrm{C}-\mathrm{H}$ & strong & $2940-2915$ & RM: 2930; PS: 2922 \\
\hline & & $\mathrm{C}-\mathrm{H}$ & strong & $2863-2843$ & RM: 2851; PS: 2844 \\
\hline & & $\mathrm{C}-\mathrm{H}$ & medium & $1485-1445$ & RM: 1457; PS: overlapping \\
\hline \multirow[t]{2}{*}{ Ethers } & 5-ring-ethers & C-O-C & strong & $1080-1060$ & RM: overlapping; PS: 1075 \\
\hline & & $\mathrm{C}-\mathrm{O}-\mathrm{C}$ & medium & $920-905$ & RM: 932; PS: 905 \\
\hline \multirow[t]{2}{*}{ Ethers } & 6-ring-ethers & $\mathrm{C}-\mathrm{O}-\mathrm{C}$ & strong & $1110-1090$ & RM: overlapping; PS: 1103 \\
\hline & & $\mathrm{C}-\mathrm{O}-\mathrm{C}$ & medium & $820-805$ & RM: 818; PS: overlapping \\
\hline
\end{tabular}


Figures

A

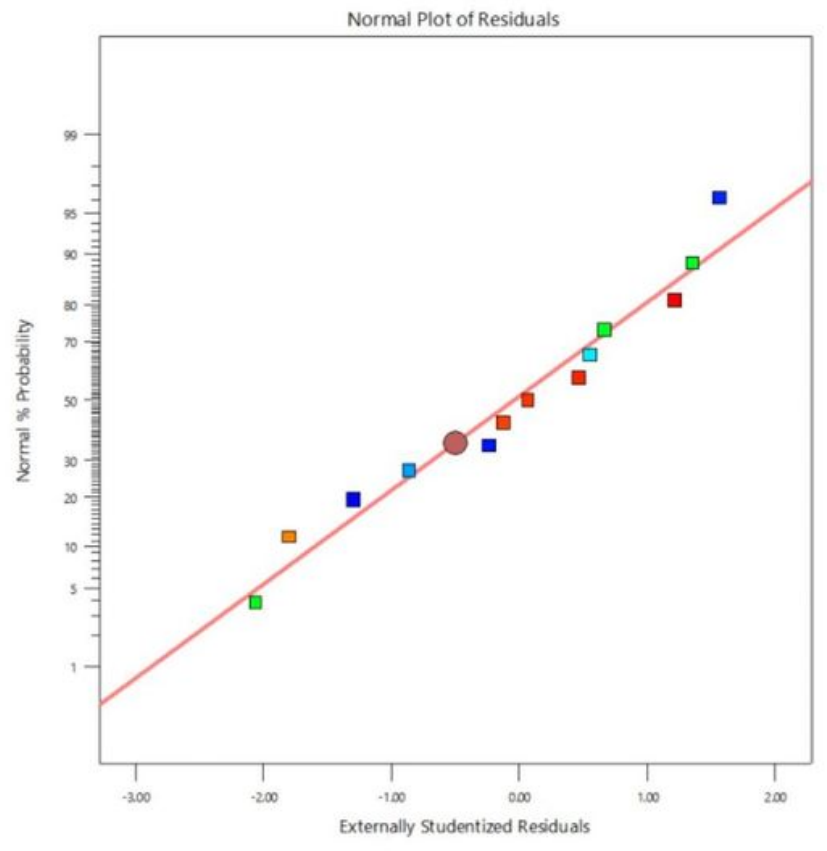

B

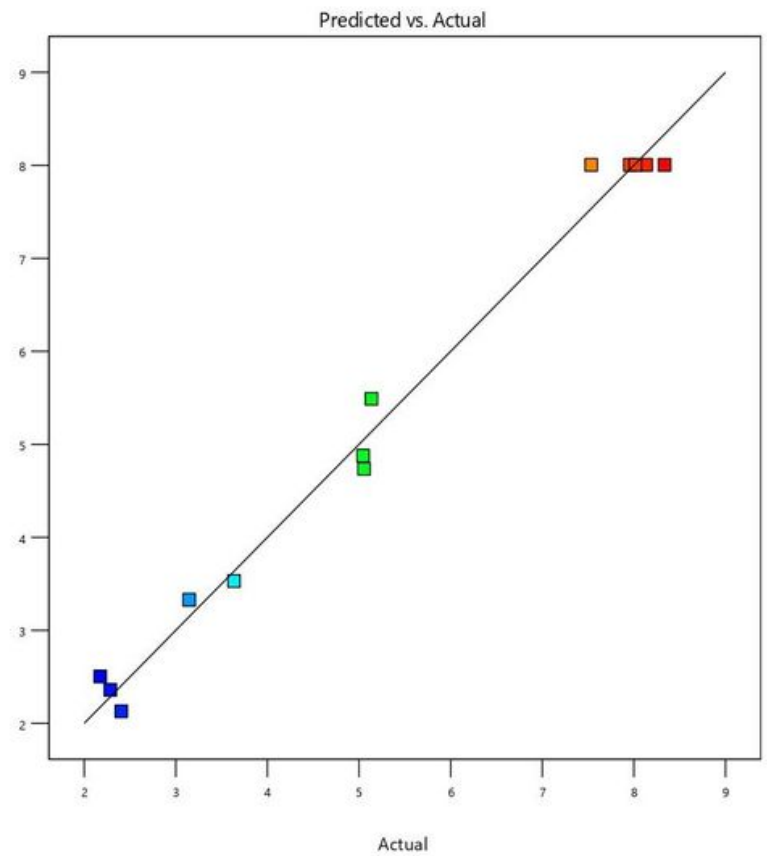

Figure 1

(A) Normal plot of residuals and (B) predicted vs. actual values for the quadratic model of yield with a ration of solvent/mass of garlic waste and temperature of solvent extraction.
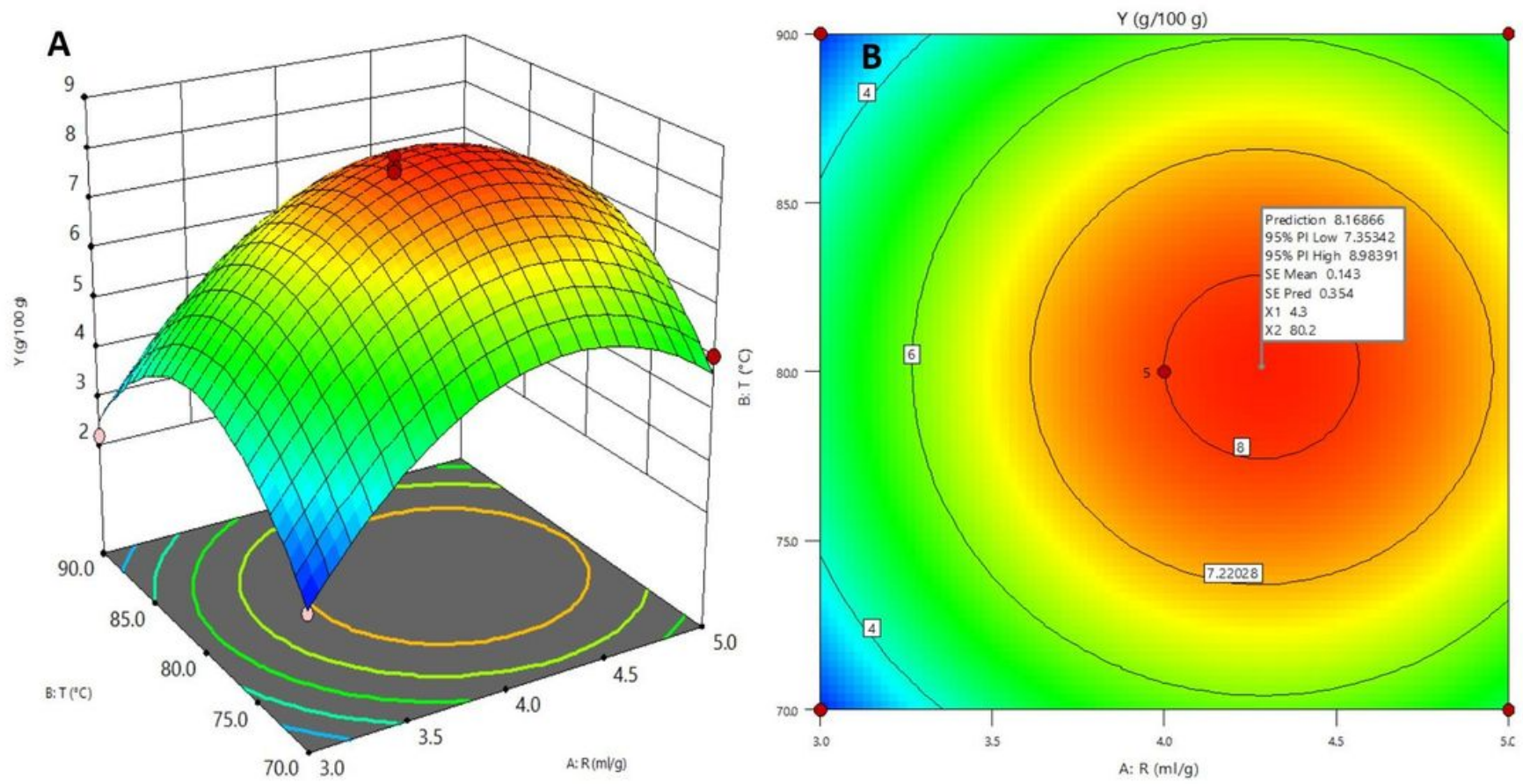

Figure 2 
(A) 3D-graph representation of the quadratic model with experimental points, and (B) Contour representation of the model with the optimal value of $Y \max =8.167 \mathrm{~g} / 100 \mathrm{~g}$ of garlic waste at $R^{\star}=4.3$ $\mathrm{mL} / \mathrm{g}$ and $\mathrm{T}^{\star}=80.2^{\circ} \mathrm{C}$.

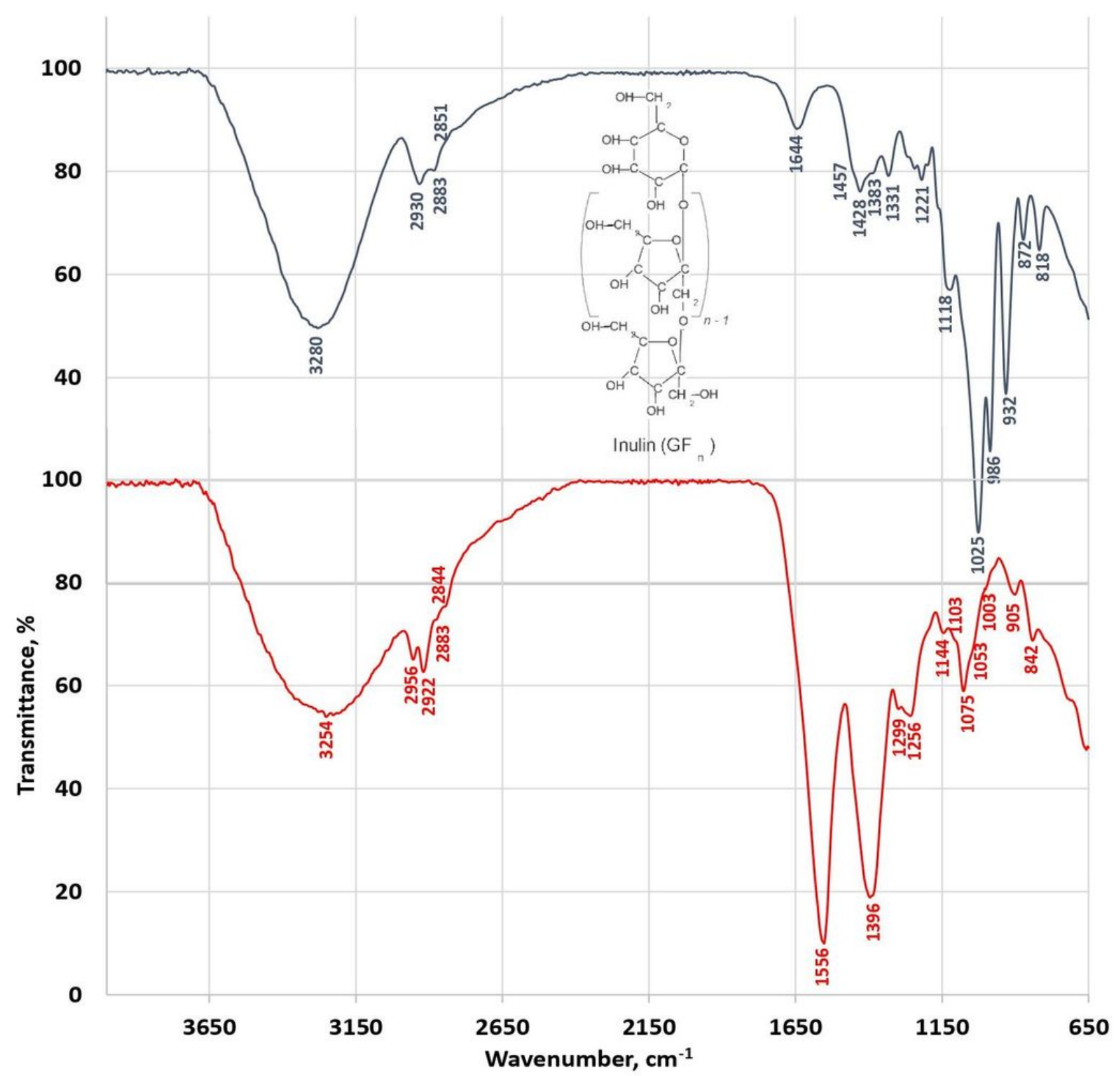

Figure 3

FTIR spectrum of reference material from Sigma-Aldrich (RM, upper) and purified sample (PS, lower).

\section{Supplementary Files}

This is a list of supplementary files associated with this preprint. Click to download. 
- GraphicalAbstract.tiff 